\title{
BIO-ECONOMICS OF DIFFERENT DRY DIRECT SEEDED WINTER RICE BASED INTERCROPPING SYSTEMS UNDER VARYING FERTILIZER MANAGEMENT
}

\author{
A. Akhter ${ }^{1}$,M.P. Anwar ${ }^{1,2, *}$, M. Begum ${ }^{1}$, S. Yeasmin ${ }^{1,2}$, M.I. Rabeya ${ }^{1}$, R. Islam $^{3}$ and A.K.M.M. \\ Islam $^{1,2}$ \\ ${ }^{1}$ Department of Agronomy, Bangladesh Agricultural University, Mymensingh-2202 \\ ${ }^{2}$ Agro Innovation Laboratory, Department of Agronomy, Bangladesh Agricultural University, Mymensingh-2202 \\ ${ }^{3}$ Department of Seed Science and Technology, Bangladesh Agricultural University, Mymensingh-2202, Bangladesh \\ *Corresponding E-mail: parvezanwar@bau.edu.bd
}

(Received: 19 February 2020, Accepted: 26 February 2020)

Keywords: Aerobic rice, leafy vegetable, intercropping, fertilizer requirement, yield, benefit cost ratio

\begin{abstract}
The experiment was conducted at the Agronomy Field Laboratory, Bangladesh Agricultural University, Mymensingh during February to June 2017 to study the feasibility of different direct seeded rice based intercropping systems under varying fertilizer management. The experiment was conducted in afactorialrandomized complete block design with three replications. Four leafy vegetables viz., gimakalmi, Indian spinach, red amaranth andjute were intercropped with dry direct seeded boro rice (cv. BRRI dhan28) following three fertilizer dose such as 100,75 and $125 \%$ of recommended fertilizer, and sole rice was also maintained as control. Rice yield was the highest $(3.87 \mathrm{t}$ $\mathrm{ha}^{-1}$ ) in sole cropping, and intercroppingresulted insignificant rice yield reduction. Although inintercropping rice yielddecreased, but increased both gross margin and benefit cost ratio (BCR) as compared to rice sole cropping. Among the vegetables, gimakalmi performed the best followed by red amaranth in terms of yield and $125 \%$ recommended fertilizer was the best fertilizer dose. Gimakalmi intercropped with rice following 125\% recommended fertilizer showed the highest gross return and BCR (2.53). Therefore, vegetables like gimakalmi and red amaranth couldbe recommended as intercrop with dry direct seeded winter rice with $125 \%$ recommended fertilizer for better productivity and higher economicreturn.
\end{abstract}

\section{Introduction}

Among field crops, rice is most widely grown under irrigated condition requiring about $50 \%$ of the total amount of water diverted for irrigation, which itself accounts for $80 \%$ of the amount of fresh water consumed(Farooq et al., 2009). Dry direct seeding rice is considered as a water saving technology having some advantages over puddled transplanted system (Humphreys et al., 2005; Zhao et al., 2007; Anwar et al., 2012; Rahman, 2019).If winter rice is grown following dry direct seeded system, 40-60\% irrigation water (compared with traditional flood irrigated system) could be saved (Anwar et al., 2010; Rahman et al., 2017; Arefinet al., 2018). In dry direct seeded system, rice is direct seeded on dry soil and moisture content of rice field is kept around or below field capacity. Fortunately, field condition of dry direct seeded rice is favorable for growing different vegetables as intercrop. Therefore, intercropping in direct seeded rice with vegetables may be considered as a viable option to maximize productivity and economic return (Rabeyaet al., 2018).

In intercropping system, proper use of fertilizer is very important to ensure the maximum harvest of both main and intercrop. Optimum rate of fertilizer plays a vital role in growth and development of rice plant(Miah et al., 2017; Sarkeret al., 2018; Jahanet al., 2018). Rice growth is remarkably hampered 
when fertilized with lower dose which drastically reduces yield. Potential yieldof a crop can be achieved only when the nutrients are applied at optimum dose which is required by the crop plants.On the other hand, excessive fertilization encourages excessive vegetative growth which makes the plant susceptible to insect, pest and diseases and ultimately reduces yield. So, it is essential to find out the optimum rate of fertilizer application for better productivity and higher economic return of rice vegetable intercropping systems. But no work has so far been done on this aspect. The present study was thereforeconducted to evaluate the productivity and profitability of different dry direct seeded winter rice based intercropping systems under varying fertilizer levels, and to optimize fertilizer requirement for this system.

\section{Materials and Methods}

The experiment was carried out at the Agronomy Field Laboratory, Bangladesh Agricultural University, Mymensingh $\left(24^{\circ} 75^{\prime} \mathrm{N}\right.$ latitude and $90^{\circ} 50^{\prime} \mathrm{E}$ longitude and at an altitude of $\left.18 \mathrm{~m}\right)$, during February to June 2017. The experimental field was medium high land under the agro-ecological zone of Old Brahmaputra Floodplain (AEZ-9).The field was medium high land having well-drained silty loam floodplain soil with $\mathrm{pH}$ 6.8. The average air temperature, rainfall (monthly total), relative humidity (monthly average) and sunshine hours (monthly total) during the experimental period ranged from $22.1-28.8^{\circ} \mathrm{C}, 0.20-496.1 \mathrm{~mm}, 74.7-84.9 \%$ and $97.8-191.6 \mathrm{hr}$.,respectively. The experiment included 2 factors; factor A: intercropping systems (5)such as (i) rice (sole), (ii) rice + gimakalmi, (iii) rice + Indian spinach, (iv) rice + red amaranth, (v) rice + jute, and factor B: fertilizer management (3)such as (i) $100 \%$ of recommended fertilizer (RF)for rice, (ii) $75 \%$ RF, (iii) $125 \%$ RF. Sole leafy vegetable plots ofgimakalmi, Indian spinach, red amaranth and jute were also maintained only for calculating land equivalent ratio. The experiment was laid out in afactorial randomized complete block design (RCBD) with three replications. The unit plot size was $4.0 \mathrm{~m} \times 4.0 \mathrm{~m}$. A brief description of the crop varieties used in this experiment is given in Table 1.

Table 1.Characteristics of the crop varieties

\begin{tabular}{|c|c|c|c|c|}
\hline Crop & $\begin{array}{l}\text { Cultivar/ } \\
\text { variety }\end{array}$ & $\begin{array}{l}\text { Days to } \\
\text { harvest }\end{array}$ & $\begin{array}{l}\text { Yield } \\
\left(t_{\text {ha }}^{-1}\right)\end{array}$ & $\begin{array}{l}\text { Developed/ } \\
\text { marketed by }\end{array}$ \\
\hline Rice (Oryza sativa) & BRRI dhan28 & $133-136$ & $5-6$ & BRRI \\
\hline Gimakalmi (Ipomoea reptans) & Evergreen 25 & $20-30$ & $40-45$ & Metal Seed Ltd. \\
\hline Indian spinach (Basella alba) & Read Leaf & $35-40$ & $20-25$ & Metal Seed Ltd. \\
\hline Red amaranth (Amaranthuscruentus) & Altapeti-20 & $30-35$ & $9-10$ & LalTeer Seed Ltd. \\
\hline Jute (Corchoruscapsularis) & CVL-1 & $30-35$ & $7-8$ & BJRI \\
\hline
\end{tabular}

BRRI = Bangladesh Rice Research Institute, BJRI = Bangladesh Jute Research Institute

The land was dry ploughed followed by harrowing and leveling without puddling to obtain a smooth seedbed. Recommended fertilizer dose were $300,125,80,80 \mathrm{~kg} \mathrm{ha}^{-1}$ of urea, triple super phosphate, muriate of potash and gypsum (100\%), respectively. All fertilizers except urea were applied as basal dose. Urea was top dressed in three equal splits at 15, 30 and 45 days after sowing (DAS). The plots were fertilized as per treatments. Sprouted rice seeds were sown on 13 February 2017 in $75 \mathrm{~cm}$ wide alternate strip in each plot. Red amaranth, jute, gimakalmi, Indian spinach were seeded as intercrop between two rice strips. In rice, spacing was maintained as $15 \mathrm{~cm} \times 15 \mathrm{~cm}$. Jute and red amaranth were broadcast while gimakalmi and Indian spinach were sown in line maintaining $25 \mathrm{~cm} \times 25 \mathrm{~cm}$ and 37.5 $\mathrm{cm} \times 15 \mathrm{~cm}$ spacing. Seed rate used for jute, gimakalmi, Indian spinach, red amaranth were 8, 9, 12, 2.5 $\mathrm{kg} \mathrm{ha}^{-1}$, respectively. Red amaranth and jute seeds were sown twice at the same day of rice sowing and at 35 days after rice sowing. While, gimakalmi and Indian spinach were sown once at the same day of rice sowing. A light irrigation was given just after sowing for proper seed germination and better seedling establishment. Anothertwo irrigations were given at 30 and 60 DAS. After every irrigation 
excess water was drained out immediately to avoid damage to vegetables. No major disease infestation was noticed either in rice or in vegetables. Only Cup 50 EC was sprayed @20 ml10 L-1 water at 40 DAS to prevent cutworm infestation in vegetables.Grain yield was recorded after harvesting the whole plot and was converted to tha ${ }^{-1}$ (14\% moisture content).Leafy vegetables were harvested at maturity and fresh weight was taken immediately after harvest and converted to $t \mathrm{ha}^{-1}$.All non-material and material costs constituted the variable cost were considered. Eight working hours of a labor was considered as a man-day, irrigation cost, cost of seed, fertilizer cost etc. were included in variable cost. Gross return was computed by adding market values of grain yield, straw yield and vegetable yield together.

Gross margin $=$ Gross return - Total Variable cost

The relative yield of a crop $=\frac{\text { Yield of component crops }}{\text { Yield of sole crop }}$

Rice equivalent yield (for vegetables) $=\mathrm{Y}_{\mathrm{r}}+\frac{\mathrm{Y}_{\text {int } \times} \mathrm{P}_{\text {int }}}{\mathrm{P}_{\mathrm{r}}}$

Here, $Y_{r}=$ Yield of rice, $P_{r}=$ sales price of rice, $Y_{i n t}=$ yield of intercrop (jute, gimakalmi, Indian spinach and red amaranth), $\mathrm{P}_{\text {int }}=$ sale price of intercrop

Land equivalent ratio $=\frac{\text { Intercrop yield of rice }}{\text { Sole yield of rice }}+\frac{\text { Intercrop yield of vegetable }}{\text { Sole yield of vegetable }}$

Benefit cost ratio $(\mathrm{BCR})=\frac{\text { Gross income }}{\text { Total cost }}$

The collected datawere analyzed using "Analysis of Variance" technique with the help of computer package, MSTAT-C, and the significance of themean differences was adjudged by the Duncan's Multiple Range Test.

\section{Results and Discussion}

\section{Rice yield parameters}

Among the yield parameters, effective tillers hill ${ }^{-1}$ and grains panicle ${ }^{-1}$ were significantly affected by intercropping systems and fertilizer management but 1000-grain weightinsignificant (Table 2).Intercropping with jute and Indian spinach showed no adverse effect on effective tiller and grain production, but with gimakalmi and red amaranth resulted in reduced number of effective tillers hill ${ }^{-1}$ and grains panicle ${ }^{-1}$ compared to rice sole culture. Both effective tillers hill ${ }^{-1}$ and grains panicle ${ }^{-1}$ was gradually increased with the increasing level of fertilizer application.

\section{Rice yield}

Grain yield of rice was significantly affected by intercropping system, fertilizer management (Table 2) and their interaction (Table 3). Highest rice yield was obtained from sole culture and intercropping resulted in significant yield reduction. Rice yield was drastically reduced when intercropped with gimakalmi or red amaranth $(>46 \%)$, while jute and Indian spinach intercropping resulted in around $30 \%$ yield reduction. Results showed that rice yield was increased gradually with the every increment of fertilizer rates which confirms demand of higher than recommended fertilizers while intercropping. Among the interactions, sole rice coupled with 125\% RF yielded the highest followed by 100 and $75 \%$ RF. The lowest grain yield was recorded when gimakalmi was intercropped with rice at $75 \%$ recommended fertilizer which was statistically similar to red amaranth intercropped rice following $75 \%$ recommended fertilizer. 
Table 2.Effect of intercropping systems on yield contributing characters and yield of rice

\begin{tabular}{|c|c|c|c|c|}
\hline $\begin{array}{l}\text { Intercropping } \\
\text { systems }\end{array}$ & $\begin{array}{l}\text { Effective tillers } \\
\text { hill }^{-1} \text { (no.) }\end{array}$ & $\begin{array}{c}\text { Grains } \\
\text { panicle }^{-1}(\text { no. })\end{array}$ & $\begin{array}{c}\text { 1000- grain } \\
\text { weight (g) }\end{array}$ & $\begin{array}{l}\text { Grain yield } \\
\left(\mathrm{t} \mathrm{ha}^{-1}\right)\end{array}$ \\
\hline Rice sole & $8.15 \mathrm{a}$ & $83.09 \mathrm{a}$ & 19.23 & $3.32 \mathrm{a}$ \\
\hline Rice +gimakalmi & $7.167 \mathrm{~b}$ & $79.60 \mathrm{~b}$ & 19.41 & $1.78 \mathrm{~d}$ \\
\hline Rice +Indian spinach & $8.02 \mathrm{a}$ & $82.92 \mathrm{a}$ & 19.42 & $2.38 \mathrm{~b}$ \\
\hline Rice + red amaranth & $7.22 b$ & $80.69 b$ & 19.17 & $1.79 \mathrm{~d}$ \\
\hline Rice + jute & $7.76 \mathrm{a}$ & $83.26 \mathrm{a}$ & 19.42 & $2.23 \mathrm{c}$ \\
\hline $\mathrm{S} \overline{\mathrm{x}}$ & 0.14 & 0.93 & 0.21 & 0.03 \\
\hline Level of significance & $* *$ & $*$ & NS & $* *$ \\
\hline $\mathrm{CV}(\%)$ & 5.81 & 3.42 & 3.36 & 3.64 \\
\hline \multicolumn{5}{|l|}{$\begin{array}{l}\text { Fertilizer } \\
\text { management }\end{array}$} \\
\hline $100 \% \mathrm{RF}$ & $7.88 b$ & $83.34 \mathrm{~b}$ & 19.47 & $2.44 b$ \\
\hline $75 \% \mathrm{RF}$ & $6.41 \mathrm{c}$ & $76.55 \mathrm{c}$ & 19.29 & $1.74 \mathrm{c}$ \\
\hline $125 \% \mathrm{RF}$ & $8.70 \mathrm{a}$ & $85.85 \mathrm{a}$ & 19.23 & $2.72 \mathrm{a}$ \\
\hline $\mathrm{S} \overline{\mathrm{x}}$ & 0.11 & 0.72 & 0.16 & 0.02 \\
\hline Level of significance & $* *$ & $* *$ & NS & $* *$ \\
\hline $\mathrm{CV}(\%)$ & 5.81 & 3.42 & 3.36 & 3.64 \\
\hline
\end{tabular}

In a column, figures with same letter (s) or without letter do not differ significantly whereas figures with dissimilar letter differ significantly (as per DMRT). ** Significant at $1 \%$ level of probability, * $=$ Significant at $5 \%$ level of probability, NS $=$ Not significant.

\section{Vegetable yield}

Intercropping system, fertilizer management andtheir interaction exerted influence on vegetable yield (Figure 1, 2 and 3).Gimakalmi produced the highest yield closely followed by red amaranth, while Indian spinach yielded the lowest. Like rice, vegetable yield was increased gradually with the increasing level of fertilizer.Among the interactions, the maximum vegetable yield $\left(7.03 \mathrm{t} \mathrm{ha}^{-1}\right)$ was recorded in gimakalmi intercropped with rice at $125 \% \mathrm{RF}$ which was statistically similar to that of same vegetable grown with $100 \%$ RF or red amaranth fertilized with $125 \%$ RF. The lowest vegetable yield $\left(0.90 \mathrm{t} \mathrm{ha}^{-1}\right)$ was obtained from Indian spinach applied with $75 \% \mathrm{RF}$ which was statistically similar to those of Indianspinach grown with $100 \%$ RF or jutewith $75 \% \mathrm{RF}$. 


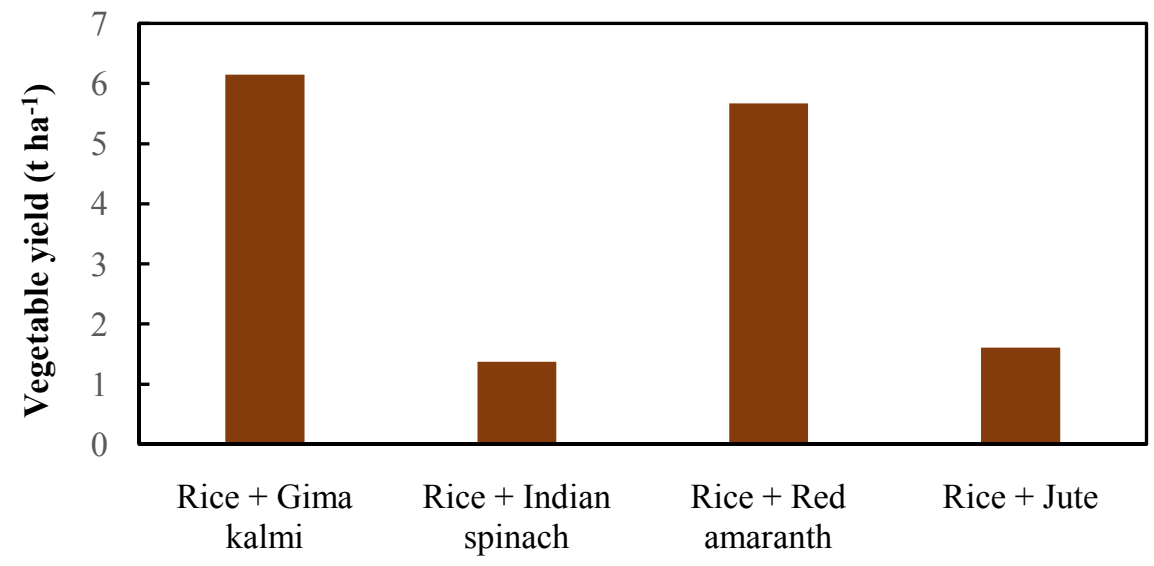

\section{Intercropping systems}

Fig. 1. Effect of intercropping systems on vegetable yield

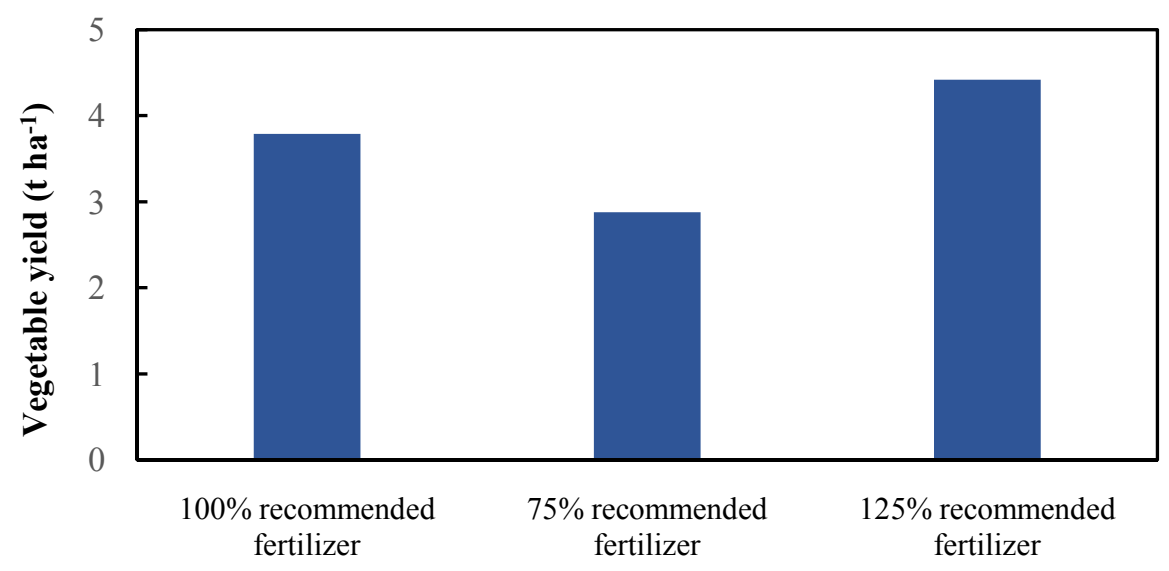

Fertilizer management

Fig. 2. Effect of fertilizer management onvegetable yield 


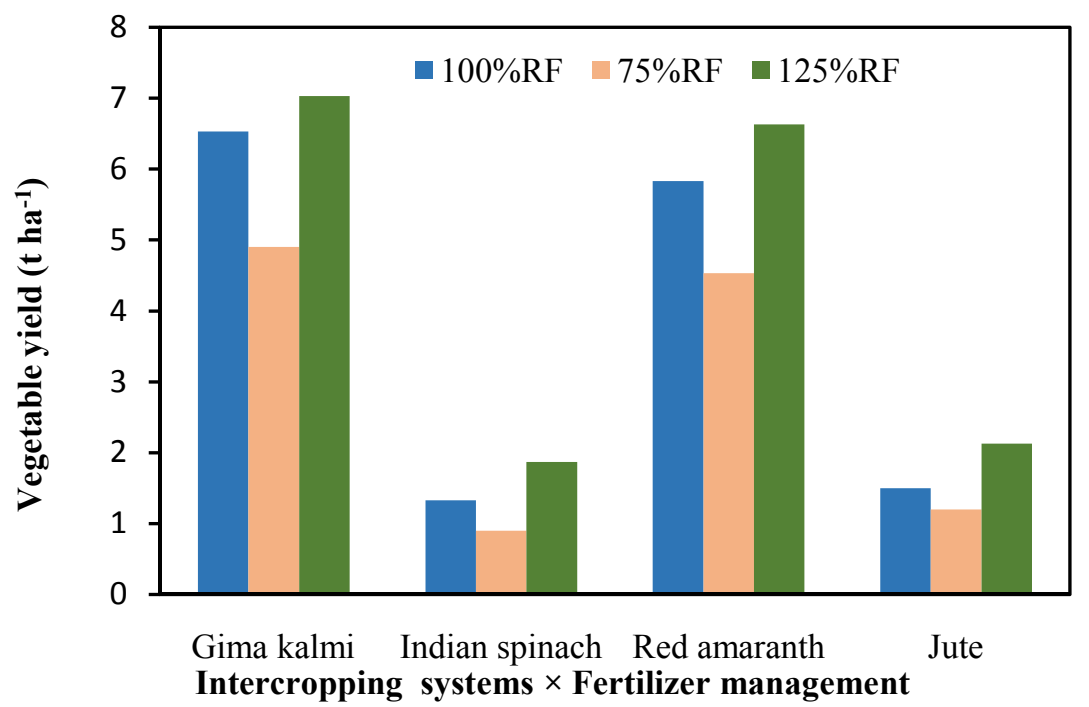

Fig.3. Yield of Vegetables as influenced by intercropping systems and fertilizer management interaction

\section{Relative yield of rice (RYR)}

Relative yield determines competitive ability of component crops in intercropping system. As shown in Table 3 , the relative yield of rice ranged from 0.44 to 0.75 , which indicates that rice yield loss was reduced by around $60 \%$ due to intercropping with different vegetables. The highest yield reduction $(63 \%)$ with of rice was occurred when gimakalmiwas intercropped with rice following $75 \%$ recommended fertilizer. On the other hand, the lowest yield reduction (16\%) was recorded in rice sole cropping following $125 \%$ recommended fertilizer.

Table 3.Rice yield, vegetable yield, relative yield of rice, equivalent yield and land equivalent ratio of intercropping systemsunder different fertilizer management

\begin{tabular}{lllllll}
\hline Interaction & & $\begin{array}{l}\text { Yield of } \\
\text { rice(tha }\end{array}$ & $\begin{array}{l}\text { Vegetable } \\
\text { (thield } \\
\text { (tha }^{-1} \text { ) }\end{array}$ & RYR & $\begin{array}{l}\text { REY } \\
\text { (tha }^{-1} \text { ) }\end{array}$ & LER \\
\hline $10 \%$ RF & Sole rice & $3.33 \mathrm{~b}$ & - & - & 3.33 & 1.0 \\
& Rice + gimakalmi & $1.89 \mathrm{fg}$ & 6.53 & 0.57 & 7.33 & 1.11 \\
& Rice + Indian spinach & $2.50 \mathrm{~d}$ & 1.33 & 0.75 & 3.83 & 1.3 \\
& Rice + red amaranth & $2.03 \mathrm{f}$ & 5.83 & 0.61 & 6.89 & 1.13 \\
& Jute & $2.47 \mathrm{~d}$ & 1.50 & 0.74 & 3.97 & 1.32 \\
\hline $75 \%$ RF & Sole rice & $2.77 \mathrm{c}$ & - & - & 2.77 & 1.0 \\
& Rice + gimakalmi & $1.23 \mathrm{i}$ & 4.90 & 0.44 & 5.31 & 0.97 \\
& Rice + Indian spinach & $1.87 \mathrm{~g}$ & 0.90 & 0.66 & 2.77 & 1.28 \\
& Rice + red amaranth & $1.33 \mathrm{i}$ & 4.53 & 0.48 & 5.11 & 1.02 \\
& Rice + jute & $1.53 \mathrm{~h}$ & 1.20 & 0.55 & 2.73 & 1.15 \\
\hline $125 \% \mathrm{RF}$ & Sole rice & $3.87 \mathrm{a}$ & - & - & 3.87 & 1.00 \\
& Rice + gimakalmi & $2.23 \mathrm{e}$ & 7.03 & 0.58 & 8.09 & 1.09 \\
& Rice + Indian spinach & $2.77 \mathrm{c}$ & 1.87 & 0.72 & 4.64 & 1.28 \\
& Rice + red amaranth & $2.03 \mathrm{f}$ & 6.63 & 0.52 & 7.56 & 1.05 \\
& Rice + jute & $2.70 \mathrm{c}$ & 2.13 & 0.70 & 4.83 & 1.26 \\
\hline
\end{tabular}




\section{Rice equivalent yield (REY)}

Table 3 showed that highest rice equivalent yield $\left(8.09 \mathrm{t} \mathrm{ha}^{-1}\right)$ was obtained from gimakalmiintercropping following $125 \% \mathrm{RF}$, while the lowest one $\left(2.73 \mathrm{t} \mathrm{ha}^{-1}\right)$ was observed in jute intercropping following $75 \% \mathrm{RF}$. Although relative yield of rice was lower than sole crop in every case, but intercropping resulted in higher yield advantage over the sole rice cropping ranged from 18.0 to $142.9 \%$.

\section{Land equivalent ratio (LER)}

Land equivalent ratio (LER) was recorded more than 1 for all the intercropping systems except Rice + gimakalmi intercropping with $75 \% \mathrm{RF}$ (Table 3 ). The LER $>1$ confirms the advantages of intercropping as compared to sole cropping, while LER $<1$ indicates a disadvantage of intercropping. The highest LER of 1.32 (Jute + rice following $100 \% \mathrm{RF}$ ) means an intercrop benefit of 0.32 . On the contrary, gimakalmi + rice intercropping following $75 \%$ RF resulted in the lowest LER of 0.97 with an intercrop loss of 0.03 .

\section{Cost benefit analysis}

Total variable cost, gross return, gross margin and benefit cost ratio (BCR) of different rice vegetable intercropping systems are presented in Table 3. Total variable cost was less in sole rice cropping following $75 \% \mathrm{RF}$ than that of other intercrop combinations. The highest total variable cost was calculated (Tk.100850 ha ${ }^{-1}$ ) for gimakalmiintercropped with rice following $125 \% \mathrm{RF}$ because of higher fertilizer dose. The total variable cost for red amaranth and jute were Tk.98525 ha ${ }^{-1}$ and Tk.92675 ha ${ }^{-1}$ at $100 \% \mathrm{RF}$, respectively. Indian spinach, on the other hand resulted in the lowest total variable cost of Tk.90325 ha ${ }^{-1}$ due to less seed rate and only onetime sowing. Data showed that the lowest gross return was calculated in sole rice. Among the intercrop species, gimakalmiintercropped with rice resulted in the highest gross return (Tk.166550 ha ${ }^{-1}$ to Tk.255300 ha ${ }^{-1}$ ) because of highest yield. On the contrary, rice intercropping with jute resulted in the lowest gross return $\left(\mathrm{Tk} .90750 \mathrm{ha}^{-1}\right)$ as well as gross margin (Tk. $2400 \mathrm{ha}^{-1}$ ) in jute-rice intercropping system following $75 \% \mathrm{RF}$ (Table 4). Among the intercrop species, gimakalmiintercropped with rice resulted in the highestgross margin(Tk.154450 ha ${ }^{-1}$ ) at $125 \%$ RF. The highest (2.53) benefit-cost ratio(BCR) was obtained from gimakalmiintercropped with rice following $125 \% \mathrm{RF}$. Second highest BCR (2.39) was obtained from red amaranth intercropped with rice following $125 \% \mathrm{RF}$. The lowest $\mathrm{BCR}$ (1.03)was found in rice intercropping with jute following $75 \%$ RF.

All the yield contributing characters except 1000-grain weight were significantly affected by intercropping systems. Similar to tillering ability, intercropping with gimakalmior red amaranth adversely affected the yield contributing characters of rice. Rice grain yield was significantly reduced in all the intercropping systems but with gimakalmior red amaranth resulted in drastic yield reduction because of the poor performances of yield parameters.Reduction in rice productivity due to intercropping has also been reported by many others (Singh et al., 1996; Rabeyaet al., 2018). Rice yield reduction was mostly the consequence of reduced number of effective tillers hill ${ }^{-1}$ and grains panicle $^{-1}$ and increased number of non-effective tillers hill ${ }^{-1}$. As reported by many researchers (Ahmad, 1990; Saleemet al., 2000),suppressive effect of intercrop species on rice growth and yield attributes was the consequence of inter-specific competition for limited resources during early growth stage and also the incompetence of rice plants to recuperate that loss at later stages. The drastic reduction in rice productivity due to intercropping with gimakalmior red amaranth was mostly the outcome of luxuriant growth and shading effect of those vegetables on rice at early growth stage. Yield of vegetables varied widely and this was happened due to the differences in their yield potential and competitive abilities with rice.

Fertilizer management showed tremendous influence on growth, yield parameters and yield of rice, and all the parameters were gradually improved with the increasing fertilizer rates. Irrespective of intercropping system, rice yield was the highest when fertilized with $125 \%$ recommended fertilizer. Even sole rice yield also was increased with the increased fertilizer rates which indicates the poor fertility status of the experimental soil, and also confirms that the recommended fertilizer rate was not 
enough for the experimental field or study area. Mbahet al. (2007) observed that system productivity of the soybean-maize intercropping was increased with the increasing level of fertilizers. Usman et al. (2015) also reported similar findings from their study. Although different intercropping systems resulted in substantial rice yield losses, but the system productivity was increased. This might be the consequence of more efficient uses of resources due to varying plant architecture and growth duration of the component crops (Oroka and Omoregie, 2007). Rabeyaet al. (2018)also reported similar findings from their study done at the same location with same intercropping systems. Competitive behavior and aggressivity of intercrop component are mostly responsible for the yield reduction of main crop (Sullivan, 2001; Muonckeet al., 2007). Therefore, selection of intercrop species is very crucial for maximizing the system productivity.

All the intercropping systems yielded higher than rice sole-cropping in terms of rice equivalent yield in this study. Increase in rice equivalent yield due to intercropping has also been reported earlier (Joshi, 2002; Jabbaret al., 2010).Land equivalent ratio (LER) were also recorded $>1$ for all the intercropping systems (except for gimakalmifertilized with $75 \%$ RF) which endorses the advantages of intercropping over sole cropping of rice. Differences in the yielding ability among vegetable species might be responsible for the variation in LER among different intercropping systems (Rabeyaet al., 2018). Higher bio-efficiency in terms of LER in intercropping has also been documented by many researchers (Oroka and Omoregie, 2007; Ogutuet al., 2012). All the intercropping systems resulted in higher net return and benefit cost ratio than rice sole cropping. These results are in conformity with those of many researchers (Saleemet al., 2000; Rabeyaet al., 2018). This might be due to the higher yield along with higher market price of vegetables compared to those of rice.

Table 4. Cost and return analysis of rice-leafy vegetable intercropping systems under differentfertilizer management

\begin{tabular}{|c|c|c|c|c|c|}
\hline \multicolumn{2}{|c|}{ Interaction } & $\begin{array}{l}\text { Gross return } \\
\left(T k . h^{-1}\right)\end{array}$ & $\begin{array}{l}\text { Total variable } \\
\text { cost }\left(\text { Tk.ha }^{-1}\right)\end{array}$ & $\begin{array}{l}\text { Grossmargin } \\
\left(\text { Tk.ha }^{-1}\right)\end{array}$ & $\overline{\mathrm{BCR}}$ \\
\hline \multirow[t]{5}{*}{$100 \% \mathrm{RF}$} & Sole rice & 117550 & 84925 & 32625 & 1.38 \\
\hline & Rice + gimakalmi & 231450 & 99575 & 131875 & 2.32 \\
\hline & Rice + Indian spinach & 129050 & 90325 & 38725 & 1.43 \\
\hline & Rice + red amaranth & 218000 & 98525 & 119475 & 2.21 \\
\hline & Rice + jute & 133100 & 92675 & 40425 & 1.44 \\
\hline \multirow[t]{5}{*}{$75 \% \mathrm{RF}$} & Sole rice & 98100 & 80600 & 17500 & 1.22 \\
\hline & Rice + gimakalmi & 166550 & 95250 & 71300 & 1.75 \\
\hline & Rice + Indian spinach & 93750 & 86000 & 7750 & 1.09 \\
\hline & Rice + red amaranth & 160800 & 94200 & 66600 & 1.71 \\
\hline & Rice + jute & 90750 & 88350 & 2400 & 1.03 \\
\hline \multirow[t]{5}{*}{$125 \% \mathrm{RF}$} & Sole rice & 136750 & 86200 & 50550 & 1.59 \\
\hline & Rice + gimakalmi & 255300 & 100850 & 154450 & 2.53 \\
\hline & Rice + Indian spinach & 154350 & 91600 & 62750 & 1.69 \\
\hline & Rice + red amaranth & 238150 & 99800 & 138350 & 2.39 \\
\hline & Rice + jute & 160050 & 93950 & 66100 & 1.70 \\
\hline
\end{tabular}

Present study confirms the viability of cultivating leafy winter vegetables as intercrop with dry direct seeded winter rice. It is also evident that rice-vegetable intercropping results in better productivity and higher economic return compared to rice sole cropping. Based on the present findings, gimakalmi or red amaranth could be suggested as potential intercrop component of dry direct seeded winter rice. However, further site specific studies considering other agronomic and fertilizer requirement of dry direct seeded rice-leafy vegetable intercropping system aspects are necessary. Hence, it deserves further investigation to formulate the fertilizer package for different dry direct seeded rice-leafy vegetable intercropping systems. 


\section{Conclusion}

Findings of the present study confirm the feasibility of intercropping leafy vegetables especially gimakalmi and red amaranth in dry direct seeded boro rice.Although intercropping diminished rice yield, but increased both gross marginand benefit cost ratioas compared to sole rice cropping. Among the vegetables, gimakalmiperformed the best followed by red amaranth in terms of yield with $125 \%$ recommended fertilizer dose. Therefore, rice intercropping withgimakalmi following $125 \%$ recommended fertilizer could be practiced for higher profitability.

\section{Acknowledgement}

Authors thankfully acknowledge the financial grant provided by the Ministry of Science and Technology, Government of the People's Republic of Bangladesh for the project under special allocation for science and technology 2016-2017.

\section{References}

Ahmad, H.K. 1990. Studies on biological intercrop relationship and water use techniques in wheat. PhD Thesis, Department of Agronomy, University of Agriculture, Faisalabad, Pakistan.

Anwar, M.P., A.S. Juraimi,A. Man, A. Puteh, A. SelamatandM. Begum. 2010. Weed Suppressive ability of rice (Oryza sativa L.) germplasm under aerobic soil conditions. Aust. J. Crop Sci. 4: 706-717.

Anwar, M.P., A.S.Juraimi, A. Puteh, A. Selamat, M.M. Rahman and B. Samedani. 2012. Seed priming influences weed competitiveness and productivity of aerobic rice. ActaAgr. Sc. and B-S P. 62(6):499-509. doi: 10.1080/09064710.2012.662244.

Arefin, M.A., M.R. Rahman, A.N.M.A. Rahman, A.K.M.M. Islam and M.P. Anwar. 2018. Weed competitiveness of winter rice (Oryza sativa) under modified aerobic system. Arch. Agr. Environ. Sci. 3(1): 1-14. doi: 10.26832/24566632.2018.030101.

Farooq, M., S.M.A. Basra, N. Ahmad andG.Murtaza. 2009. Enhancing the performance of transplanted course rice by seed priming. Paddy Water Environ. 7: 55-63.doi: 10.1007/s10333-008-0143-9.

Humphreys, E., C. Meisner, R. Gupta, J. Timsina, H. Beecher, T.Y. Lu, Y.S. Yadvinder-Singh, M. Gill, I. Masih, Z.J. GuoandJ. Thompson. 2005. Water saving in rice-wheat systems. Plant Prod. Sci. 8:242-258. doi: 10.1626/pps.8.242.

Jabbar, A., R. Ahmad, B.I. Hussain, Z.A. Virk andS.N. Vains. 2010. Effect of different rice-based intercropping systems on rice grain yield and residual soil fertility. Pak. J. Bot. 42: 2339-2348.

Jahan, N.A., S. Yeasmin, M.P. Anwar, M.A. Islam, H. Rahman and A.K.M.M. Islam. 2018. Efficacy and economics of different need based nitrogen management approaches in winter rice. Am. J. Plant Sci. 9:2601-2611. doi: 10.4236/ajps.2018.913189.

Joshi, M. 2002. Dynamics of rice-based cropping systems in the southern transitional zone of Karnataka, India.Intl. Rice Res. 27: 41-42.

Mbah, E.U., C.O. Muoneke and D.A. Okpara. 2007. Effect of compound fertilizer on the yield and productivity of soybean and maize in soybean/maize intercrop in southeastern Nigeria. Trop. Subtrop. Agroecosyst. 7: 87-95.

Miah, H., M.P. Anwar, M.R. Rahman, S. Hoshain and K. Hossen. 2017. Minimizing nitrogen requirement of rice through foliar spray of urea. Imperial J. Interdisc. Res. 3(12): 244-254.

Muoneke, C.O., M.A.O. Ogwuche and B.A. Kalu. 2007. Effect of maize planting density on the performance of maize/soybean intercropping system in a guinea savannah agro ecosystem. Afr. J. Agric. Res.2: $667-677$. 
Ogutu, M.O., H. Ogola, J.N. OkechandN. Kidula. 2012. Rain fed rice-legume based cropping systems for sustainable food security and incomes for the small-scale farmers. East Afr. Agric. Forest. 78: 179188.

Oroka, F.O. and A.U. Omoregie. 2007. Competition in a rice-cowpea intercrop as affected by nitrogen fertilizer and plant population. Sci. Agri. 64: 621-629.doi:10.1590/S0103-90162007000600010.

Rabeya, I.M., M.P. Anwar,M.M. Rahman,A. Akhter andA.K.M.M. Islam. 2018. Intercropping of dry direct seeded boro rice with leafy vegetable for better weed suppression and higher profitability. Fundam. Appl. Agric. 3(3): 545-558.doi: 10.5455/faa.302642844.

Rahman, A.N.M.A., A.K.M.M. Islam, M.A. Arefin, M.R. Rahman and M.P. Anwar. 2017. Competitiveness of winter rice varieties against weed under dry direct seeded conditions. Agril. Sci. 8:1415-1438. doi: 10.4236/as.2017.812101.

Rahman, M.M. 2019. Potential benefits of dry direct seeded rice culture: A review. Fundam. Appl. Agric. 4(2):744-758.doi: 10.5455/faa.16534.

Saleem, M.F., S.H. Shah, M.A. Malik and M.K. Munir. 2000. Bio-economics of different upland rice-based intercropping systems under strip plantation. Int. J. Agric. Biol.2: 294-296.

Sarker, D., M.P. Anwar, M.R. Uddin and K. Hossen. 2018. Exploring the possibility of using AgroplusBiodecomposer for boosting up rice productivity under Bangladesh condition. Fundam. Appl. Agric. 3(1): 372-381. doi: 10.5455/faa.284983.

Singh, G., O.P. Singh,M. Kumar, A.L. Rajput andS. Maurya. 1996. Effect of intercrops on yield and economics, weeds and pest infestation of deep-water rice. Annu. Agric. Res.17: 14-17.

Sullivan, P. 2001. Intercropping principles and production practices.University of Arkansas, Fayetteville, USA.

Usman, M., M.G. Nangere and I. Musa. 2015. Effect of three levels of NPK fertilizer on growth parameters and yield of maize-soybean intercrop. Int. J. Sci. Res. 5(9): 2250-3153.

Zhao, C., H. Jiang, C. Ren, Y. Yin and Y. Li. 2007.Studies on key techniques of sowing rice directly on dry land for high yield and high efficiency.J. Jilin Agril. Sci.32: 9-11. 